Vukman, Péter. "Zinner, Tibor. 2013-2014. A nagy politikai affér."A Rajk-Brankov-ügy ('“The Great Political Affair" - the Rajk-Brankov Case'), vols. I-II. Budapest: Saxum. 646/702 pp."Hungarian Cultural Studies. e-Journal of the American Hungarian Educators Association, Volume 8 (2015): http://ahea.pitt.edu DOI: 10.5195/ahea.2015.209

\title{
Zinner, Tibor. 2013-2014. A nagy politikai affér.'A Rajk-Brankov-ügy ('“The Great Political Affair" - the Rajk-Brankov Case'), vols. I-II. Budapest: Saxum. 646/702 pp. ${ }^{1}$
}

\section{Reviewed by Péter Vukman, University of Szeged}

By the end of World War II, as a direct result of the westward advance of the Red Army, Central-Eastern Europe had fallen into the sphere of influence of the Soviet Union. Although historians are still debating Stalin's original aims in the region and how much scope for action he would have tolerated from local opposition forces, all agree that as the differing Soviet and American views on post-war Europe escalated into a cold war confrontation, local communist parties gained complete political control of their countries, including Hungary, with the efficient help of the Soviet Union. The show trials accompanying this process contributed to the consolidation of the new power structure as these trials offered a possibility for eliminating the real or imagined enemies of the new regimes, re-enforced the intimidation of society in general and, as a useful propaganda tool, strengthened the ideological foundation of the communist regimes in particular. The Rajk trial that took place between the sixteenth and twenty-forth of September 1949 in Budapest is considered to have served as a model for later show trials in the entire region. In total, between 1949-1950 over thirty similar trials in Hungary ended with the imprisonment of more than one hundred civilians and army officers, and nearly twenty of them were executed.

The Rajk trial not only had a significant impact on the internal situation and political developments within Hungary but also played an important role in the rapidly escalating conflict, which was first made public in June 1948, between the Soviet Union and Yugoslavia. Therefore, both the Hungarian and the Yugoslav historiographies rightly consider this trial as one of three so-called anti-Titoist trials (the other two are those of Koçi Xoxe in Albania and Traicho Kostov in Bulgaria). Even in real time it was evident that the charges were not addressed against László Rajk, the former minister of interior and of foreign affairs, but rather against Josip Broz Tito, Chairman of the Yugoslav Communist Party and the de facto leader of Yugoslavia. This connection was further emphasized by the communist propaganda machine that did not talk about the trial of László Rajk but about that of László Rajk and Lazar Brankov, chargé d'affairs of the Yugoslav Embassy in Hungary, who, according to the charges, served as an intermediary between Rajk and the Yugoslav leadership. Therefore, the trial became generally known as the

${ }^{1}$ Peter Vukman is currently researching the history of Yugoslav political emigrants in Hungary between 1948-56. His research is financed by the National Scientific Research Fund (OTKA PD 108386).

(cc) Br

ULLS D-Serle
New articles in this journal are licensed under a Creative Commons Attribution 4.0 International License.

This journal is published by the University Library System of the University of Pittsburgh as part of its D-Scribe Digital Publishing Program and is cosponsored by the University of Pittsburgh Press 
Vukman, Péter. "Zinner, Tibor. 2013-2014. Á nagy politikai affér."A Rajk-Brankov-ügy ('“The Great Political Affair" - the Rajk-Brankov Case'), vols. I-II. Budapest: Saxum. 646/702 pp."Hungarian Cultural Studies. e-Journal of the American Hungarian Educators Association, Volume 8 (2015): http://ahea.pitt.edu DOI: 10.5195/ahea.2015.209

Rajk-Brankov trial, as specified in the sub-title of the new book by Tibor Zinner, "A nagy politikai affér." A Rajk-Brankov-ügy ['"The Great Political Affair"- the Rajk-Brankov Case']. Although many case studies, articles (shorter and longer, scholarly as well as popular) have been written on this case since the early 1990s, the reader had to wait for this first comprehensive and detailed two-volume monograph.

Tibor Zinner, a renowned historian of law and since 2014 a senior researcher in the Post1945 Research Group at the Veritas Research Institute at Budapest, has now for more than two decades carried out research on the history of the reprisals and show trials that took place in Hungary after 1945. Previously he has already published numerous studies on primary sources, scientific articles and monographs (sometimes in collaboration with other scholars) on these topics, which makes his latest book the outcome and summary of a nearly life-long project. Before writing it, Zinner had carried out intensive archival research, especially in the National Archives of Hungary, in the Historical Archives of the Hungarian State Security and in the Archives of the Institute of Political History. In order to demonstrate the different points of view and opinions regarding the trial, as well as to illuminate the contradictions in archival and other contemporary sources concerning the case, Zinner extended the scope of his research to the realtime reports and daily bulletins of the Hungarian Telegraphic Agency; in addition, he also interviewed some of the leading figures in the period of the trials.

Zinner published the results of his immense research in two volumes, the first of which came out in 2013 and deals mostly with the preparations for the trial and the development of the charges against the main culprits. After he had outlined the wider international context (including the Soviet-Yugoslav conflict and Stalin's imperial aims and policies), in his 2014 volume Zinner correctly narrowed down his scope of research and focused on László Rajk and the State Security. He did that because he thought that seemingly negligible factors, like the articles published in Amerikai Magyar Népszava on the third of December 1947 and on the ninth of August 1948, could have raised the suspicion of Mátyás Rákosi, the Hungarian Communist (later changed into Workers') Party General Secretary and the country's de facto ruler, and therefore might have served as the origin of the charges against Rajk (I, 88-89). As for the inquiry that preceded the trial, Zinner distinguishes between two "safety fuses": the criminal case of American citizen Noel Havilard Field and the slandering of the Yugoslav Lazar Brankov.

Zinner persuasively argues against the generally held view of Hungarian historiography that the two parts of the inquiry leading to the trial were separate or consecutive and convincingly claims that they were expanded in parallel time and with greater emphasis on the Yugoslav charges. As a cunning politician, Rákosi, who according to Zinner had been wellknown for his sympathy towards Tito, soon realized the change of the Soviet stance toward Yugoslavia; therefore, he intended to create a monstrous anti-Titoist trial out of the diplomatic scandal surrounding the murder of Miloš Mojić, a correspondent working for the Serbo-Croat minority paper Naše novine, supposedly by Živko Boarov, the Press Secretary of the Yugoslav embassy. In order to achieve this aim, Rákosi transferred the investigation from the criminal to the political police, which, according to Zinner, "instead of [supplying] the real revelation of what had happened, symbolized the coming to the fore of domestic and foreign policy aims" (I,197).

Although Boarov's trial eventually did not materialize, the charges against Tito and the Yugoslav leadership later resurfaced against Brankov. This succession of events, argues Zinner, means that the charges against the Yugoslav chargé d'affairs already existed in the summer of 
Vukman, Péter. "Zinner, Tibor. 2013-2014. Á nagy politikai affér."A Rajk-Brankov-ügy ('“The Great Political Affair" - the Rajk-Brankov Case'), vols. I-II. Budapest: Saxum. 646/702 pp."Hungarian Cultural Studies. e-Journal of the American Hungarian Educators Association, Volume 8 (2015): http://ahea.pitt.edu DOI: 10.5195/ahea.2015.209

1948 (I, 224) and that the main lines of the anti-Yugoslav charges had already evolved by the middle of May 1949, before Brankov was decoyed from Hungary to Moscow (I, 235). Therefore, the anti-Yugoslav concept must have originated from the Hungarian, rather than from the Soviet, Communist Party leadership and from Rákosi himself, as elaborated and exemplified throughout Zinner's work. The fact that the records of Rajk's interrogation in Budapest had always preceded those of Brankov in Moscow also supports Zinner's argument; in this regard the function of the American Field's trial, too, was to point at the alleged connection between American and Yugoslav anti-Hungarian and anti-communist subversive actions.

As for making a scapegoat of Rajk, Zinner is right that Rákosi had at least three parallel motives in mind: he wanted to quiet the possible Soviet concern or dissatisfaction about himself, he wished to make the Soviets forget his earlier pro-Tito stance, and he hoped or intended to take Tito's place in the international Communist Movement by organizing a monstrous, internationally publicized anti-Titoist trial. For the achievement of these aims, he needed a person who not only belonged to the close circle of the local Hungarian communist leadership but also had a significant political role in the country, and Rajk, who was executed in 1949, was just the right person. Zinner sees May 1949 as an important turning point in the preparation of the charges, as during this month both Field and Brankov were enticed to travel to Prague and Moscow, respectively, and then arrested. Lieutenant-colonel Ernő Szücs took over the overall management of the prosecution, mixed Soviet-Hungarian commissions interrogated the main suspects, and a separate commission started to compare and evaluate the various reports of the interrogation (I, 429).

Zinner scrutinizes the preparation of the trial in minute detail in the first part of his second volume, highlighting the role played by the members of the Central Committee of the Hungarian Workers' Party, and by Rákosi specifically, in the process. In this volume's second and much larger part Zinner deals with the trial itself attempting to reconstruct the courtroom sessions and dynamics, which for this reviewer is one of the most important novelties of the book, as Zinner found not only the original stenographic records of the public trial but also their revised, often modified versions along with their fair copy. The author justly considers these documents as the only authentic sources on the trial. Furthermore, by comparing these documents with the so-called Blue Book, meaning the officially published records of the indictment, the proceedings and the verdict, Zinner was able to highlight the many distortions and deceptions contained in the latter, official State publication.

In the third and last part of the second volume, after briefly referring to the Rajk-Brankov adjoining trials, Zinner analyzes the complex process of reviews of the trial starting from 1954 and, with the thoroughness of a philologist, compares between different and often inconsistent or contradictory testimonies. He argues that the review process had its own distortions and deceptions, and that Rákosi, by then appointed as Hungary's Prime Minister, again played a significant role. Zinner is right in calling the reader's attention to the fact that the protraction of the review process and the many new infringements of the law were fundamentally affected by power struggles among members of the Soviet leadership as well as by the effect of this struggle on the leaders of the Hungarian Workers' Party. Although most of the restitutions took place in two periods, first between the thirty-first of August and the eighteenth of October 1954 and then between the twelve of April and the thirtieth of November 1955, the last person to be rehabilitated, Lazar Brankov, was only cleared of all charges over forty years afterward, on the twelve of September 1997. 
Vukman, Péter. "Zinner, Tibor. 2013-2014. Á nagy politikai affér."A Rajk-Brankov-ügy ('“The Great Political Affair" - the Rajk-Brankov Case'), vols. I-II. Budapest: Saxum. 646/702 pp."Hungarian Cultural Studies. e-Journal of the American Hungarian Educators Association, Volume 8 (2015): http://ahea.pitt.edu DOI: 10.5195/ahea.2015.209

Although Zinner's book provides the reader with many valuable sources of information about even the tiniest details of the preparations, the proceedings and the review of the trial, the numerous quotations (sometimes longer than necessary) and the abundance of names, events and data often distracts the reader's attention from the main story line; in this regard the book could have profited from a tighter editing. In addition, although the author briefly deals with the international context and impact of the trial at the beginning of his first volume, this reviewer still thinks that a more detailed introductory chapter about the origins and escalation of the Soviet-Yugoslav conflict as well as about the development of the Rákosi regime in Hungary, including a brief summary of the show trials in Hungary throughout 1947-1949, would have been in place for readers to be able to grasp the Rajk-Barnkov case within its fullest framework.

The author may have also expressed his opinion on the thesis of Harvard University Polish-American historian Adam Ulam regarding the system-specific aspects of show trials in State Socialist regimes, especially as Zinner does refer at times to the similarities between the Moscow trials of the 1930s and the Rajk trial. Zinner should also have laid more emphasis on the questionable character of the Hungarian State Security Authorities documents within the short chapter that he devotes to the issue of sources in his book (I, 9-19). Even though he treats such sources with sufficient suspicion, Zinner refers explicitly to this major methodological problem underlying his entire endeavor only on page 178 of his first volume. Lastly, the non-historian educated reader would have benefited from a separate chapter concerning the later SovietYugoslav process of relations normalization and its effect on the Hungarian-Yugoslav relationship, which could make it easier to understand the Rajk-Brankov review trial's complex internal and international context.

Although Zinner strives for the greatest possible degree of precision, some factual inaccuracies still missed his all-embracing attention. For example, historians do not generally consider the Slánsky trial as an anti-Titoist but rather as an anti-Zionist one (I, 27-28); the opening of the Fifth Congress of the Yugoslav Communist Party did not coincide with Boarov's arrest but preceded it in five days (I, 207); and Yugoslavia did exist as a State already in 1935 (II, 46), and even under the official title of The Kingdom of the Serbs, Croats and Slovenes (as early as 1918-1929) it was widely referred to as Yugoslavia. Zinner likewise contradicts himself on the question of Rákosi's attendance at a session of the Political Committee on the sixth of October 1954: he first states that Rákosi rendered an account on the process of restitution at that meeting and then writes that the decision on the further agenda of the process was made in Rákosi's absence at the same session (II, 427), when in fact the discussion of the agenda took place in another meeting two weeks later, on the twentieth of October 1954.

Regardless of these critical remarks, it has to be acknowledged that Tibor Zinner has provided the first full and detailed analysis of an important event in Hungarian post-1945 history. His argumentation is clear, convincing and buttressed by a huge amount of relevant primary sources. Although its vast amount of information is not always easy to absorb at first reading, Zinner's two-volume monograph is a valuable contribution to contemporary Hungarian history; hopefully, it should be read not only by historians but also by the general Hungarian speaking public wherever it presently lives. 